\title{
Synthesis and Spectral Studies of Ru(II) Carbonyl Schiff Base Complexes
}

\author{
B. Prabhakaran ${ }^{1}$, N. Santhi ${ }^{2}$, M. Emayavaramban ${ }^{2}$ \\ ${ }^{1}$ Department of Research \& Development, Emcure Pharmaceuticals Ltd, Pune - 411057, India \\ ${ }^{2}$ Department of Chemistry, Government Arts College, C. Mutlur, Chidambaram - 608102, India \\ E-mail address: prabhukaran.chem@gmail.com
}

\begin{abstract}
The synthesis and characterization of hexa co-ordinated ruthenium(II) complexes of the type $[\mathrm{Ru}(\mathrm{CO})(\mathrm{B})(\mathrm{L})]$ (where $\mathrm{B}=\mathrm{PPh}_{3}, \mathrm{AsPh}_{3}$, py or pip and $\mathrm{L}=$ dibasic tetradentate Schiff base ligand) were synthesized from the reaction of $\left[\mathrm{RuHCl}(\mathrm{CO})(\mathrm{B})\left(\mathrm{EPh}_{3}\right)_{2}\right]\left(\right.$ where $\mathrm{E}=\mathrm{P}, \mathrm{B}=\mathrm{PPh}_{3}$, py or pip, $\mathrm{E}=$ As, $\mathrm{B}=\mathrm{AsPh}_{3}$ ) with different tetradentate ligands. The ligands were derived by the condensation of 5chloro-4-methyl-2-hydroxy benzophenone with ethylenediamine, propylenediamine and $o$-phenylenediamine in 1:1 molar ratio. All the compounds have been characterized by elemental analysis and spectral (FT-IR, UV-VIS and ${ }^{1} \mathrm{H}-\mathrm{NMR}$ ) methods. An octahedral environment around $\mathrm{Ru}(\mathrm{II})$ ion has been tentatively proposed for all the complexes
\end{abstract}

Keywords: Schiff Base; ruthenium(II) complexes; tetradentate ligands; octahedral environment

\section{INTRODUCTION}

The interest in the synthesis and characterization of transition metal complexes containing Schiff bases lie in their biological and catalytic activity in many reactions ${ }^{1,2}$. Transition metal complexes, with ligands containing both hard and soft donor groups, have been used extensively in coordination and organometallic chemistry. The majority of such ligands are functionalized phosphines where the phosphorus is a soft donor and either oxygen or nitrogen is a hard donor ${ }^{3,4}$.

Over the past few years $\mathrm{N}_{2} \mathrm{~S}_{2}$ and $\mathrm{N}_{2} \mathrm{O}_{2}$ Schiff base ligands have been extensively investigated with regard to their numerous applications in organic synthesis as well as medicine ${ }^{5}$. Schiff bases have played a special role as chelating ligands in main group and coordination chemistry, mainly due to their stability under a variety of oxidative and reductive conditions ease of preparation, and to the fact that imine ligands are borderline between hard and soft Lewis bases ${ }^{6-8}$.

Schiff base complexes have been particularly valuable for designing complexes of widely different structural type. The possibility of having lone pair of electrons in either $\pi$ or 
$\mathrm{sp}^{2}$ hybridized orbital or trigonally hybridized nitrogen in the azomethine group is of fundamental chemical and biological importance.

A large number of transition metal phosphine complexes have been used in catalysis due to the characteristic steric and electronic properties of the tertiaryphosphine ligands ${ }^{9}$ In the past decade there has been a growing interest in reactions that include these type of ligands and complexes, which have proved to be active catalysts in processes such as the hydrogenation of aldehydes ${ }^{10}$ and aromatic ketones ${ }^{11}$ or the carbonylation of metal methyl bonds ${ }^{12}$, as therapeutic agents in anticancer drugs ${ }^{13}$ or as structural fragments or polystyreneimmobilized catalysts ${ }^{14}$.

Further, the interest in the chemistry of ruthenium ${ }^{15-19}$ is primarily due to its fascinating redox, electron transfer, and energy transfer properties and its ability to have a wide range of oxidation states $(-2$ to +8$)$. Due to these characteristics large variety of ruthenium complexes have found wide applications including artificial photosynthesis, photo molecular devices electron transfer properties of proteins and DNA, catalytic oxidation of water and organic substrates. Furthermore, transition metal complexes of tetradentate Schiff base ligands find applications in catalysis ${ }^{20-22}$ and as biomimetic enzyme models ${ }^{23-27}$.

In view of growing interest in the Schiff base metal complexes, the synthesis and characterization of a series of ruthenium(II) carbonyl complexes containing Schiff bases and triphenylphosphine/arsine have been carried out in this paper.

\section{EXPERIMENTAL METHODS}

Commercially available $\mathrm{RuCl}_{3} \cdot 3 \mathrm{H}_{2} \mathrm{O}$ was used as supplied from Loba Chemie. All the reagents used were chemically pure and annular grade. The solvents were freshly distilled before use. The analysis of carbon, hydrogen and nitrogen were performed at Sophisticated Test and Instrumentation Centre (STIC) Cochin University, Kochi. Infra-red spectra of complexes were recorded in $\mathrm{KBr}$ pellets with a Perkin - Elmer 597 spectrophotometer in the range 4000-400 $\mathrm{cm}^{-1}$. Electronic spectra of the complexes were recorded in $\mathrm{CHCl}_{3}$ solution with a Cary 300 Bio UV-Vis Varian spectrophotometer in the range $800-200 \mathrm{~nm}$. The ${ }^{1} \mathrm{H}-$ NMR spectra were recorded in $\mathrm{CDCl}_{3}$ with Bruker $400 \mathrm{MHz}$ instrument using TMS as internal reference. Melting Point was recorded in the Boeties micro heating table and is uncorrected.

\section{1. Preparation of Ru(II) precursor complexes}

\section{1. 1. Carbonylchlorohydridotris(triphenylphosphine) ruthenium(II), $\left[\mathrm{RuHCl}(\mathrm{CO})\left(\mathrm{PPh}_{3}\right)_{3}\right]$}

A solution of $0.26 \mathrm{~g}(1.0 \mathrm{~mol})$ of hydrated ruthenium trichloride in $20 \mathrm{ml}$ of 2-methoxyethanol and aqueous formaldehyde $(20 \mathrm{ml} ; 40 \%)$ were added rapidly and successively to a vigorously stirred boiling solution of $1.58 \mathrm{~g}$ (6 moles) of triphenyl phosphine in $60 \mathrm{ml}$ of 2-methoxyethanol. The mixture was heated under reflux for 10 minutes and allowed to cool. The precipitate that formed was separated and washed successively with ethanol (small quantity), water, n-hexane, dried in vacuum. Colour: Cream white, M.P: 210 ${ }^{\circ} \mathrm{C}$, Yield: $75 \%$ 


\section{1. 2. Carbonylchlorohydridopyridine bis(triphenylphosphine) ruthenium(II), $\left[\mathrm{RuHCl}(\mathrm{CO})(\mathrm{py})\left(\mathrm{PPh}_{3}\right)_{2}\right]$}

$\left[\mathrm{RuHCl}(\mathrm{CO})\left(\mathrm{PPh}_{3}\right)_{3}\right]^{1}(0.24 \mathrm{~g} ; 0.24 \mathrm{mmol})$ was added to benzene $(20 \mathrm{ml})$ containing pyridine $(0.5 \mathrm{ml})$ and the mixture was stirred at room temperature for 24 hours under nitrogen atmosphere. The green solution was concentrated in vacuum and the solid that separated by adding Pet. Ether was washed with hexane, ether to get a green microcrystalline solid Colour: Green, M.P: $175^{\circ} \mathrm{C}$, Yield: $70 \%$

\section{1. 3. Carbonylchlorohydridopiperidinebis(triphenylphosphine) ruthenium(II), $\left[\mathrm{RuHCl}(\mathrm{CO})(\mathrm{pip})\left(\mathrm{PPh}_{3}\right)_{2}\right]$}

$\left[\mathrm{RuHCl}(\mathrm{CO})\left(\mathrm{PPh}_{3}\right)_{3}\right]^{1}(0.24 \mathrm{~g} ; 0.24 \mathrm{mmol})$ was added to benzene $(20 \mathrm{ml})$ containing piperidine $(0.5 \mathrm{ml})$ and the mixture was stirred at room temperature for 24 hours under nitrogen atmosphere. The green solution was concentrated in vacuum and the solid that separated by adding pet. ether was washed with hexane, ether to get a green microcrystalline solid. Colour: Pink, M.P: $117^{\circ} \mathrm{C}$, Yield: $60 \%$

\section{1. 4. Carbonylchlorohydridotris(triphenylarsine) ruthenium(II), $\left[\mathrm{RuHCl}(\mathrm{CO})\left(\mathrm{AsPh}_{3}\right)_{3}\right]$}

A solution of $0.29 \mathrm{~g}$ of hydrated ruthenium trichloride in 2-methoxyethanol $(5 \mathrm{ml})$ and aqueous formaldehyde $(20 \mathrm{ml}, 40 \%)$ were added rapidly and successively to a vigorously stirred boiling solution of $1.58 \mathrm{~g}$ of triphenylarsine in $60 \mathrm{ml}$ of 2-methoxyethanol.The mixture was heated under reflux for 1 hour and allowed to cool. The precipitate that formed was separated and washed with ethanol and n-hexane, dried in vacuo. Colour: Yellow, M.P: 180 ${ }^{\circ} \mathrm{C}$, Yield: $70 \%$

\section{2. Preparation of Schiff base ligands}

\section{Scheme I: Preparation of 4-chloro-3-methyl phenyl benzoate}

$7.13 \mathrm{~g}$ of 4-chloro-3-methyl phenol was dissolved in $75 \mathrm{ml}$ of $10 \% \mathrm{NaOH}$ solution contained in a reagent bottle or conical flask of about $200 \mathrm{ml}$ capacity. Add $8.64 \mathrm{ml}$ of redistilled benzoyl chloride was added, cork the vessel securely and the mixture was shaken vigorously for $15-20 \mathrm{~min}$. At the end of this period the reaction was usually completed and the solid product was obtained. Filtered if the solid ester with solution breaks up if any lumps on the filter, washed thoroughly with water and drained well. The crude ester was recrystallized from rectified spirit, a quantity of hot solvent was used trice the minimum volume required for complete solution.

The product was filtered as a colourless crystals. 

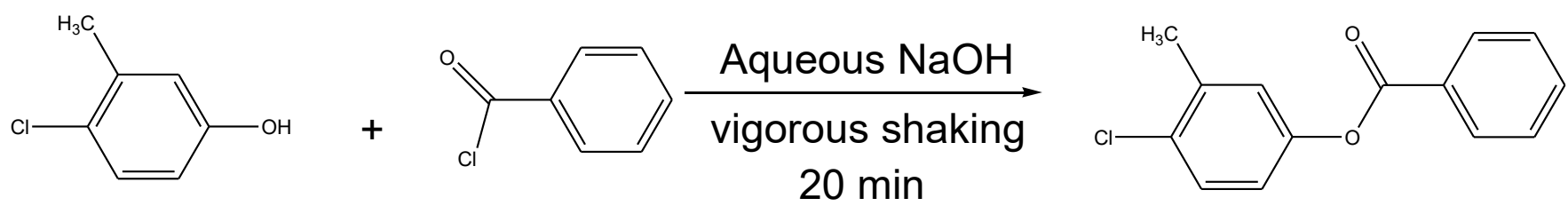

Scheme II: Preparation of 5-chloro-4-methyl-2-hydroxybenzophenone

Anhydrous $\mathrm{AlCl}_{3}(7.5 \mathrm{~g})$ was heated in an oil bath at $140{ }^{\circ} \mathrm{C}$ for $5 \mathrm{~min}$ and the compound 4-chloro-3-methyl phenyl benzoate $(2 \mathrm{~g})$ was added with stirring. The temperature was allowed to rise to $170-180^{\circ} \mathrm{C}$ and maintained for $20 \mathrm{~min}$. After cooling, the compound was added to $200 \mathrm{ml}$ of $2 \mathrm{~N} \mathrm{HCl}$.

The insoluble material was filtered, washed and dried. The crude product was recrystallised from hot ethanol to give pale green needle shape crystals.<smiles>Cc1cc(OC(=O)c2ccccc2)ccc1Cl</smiles>

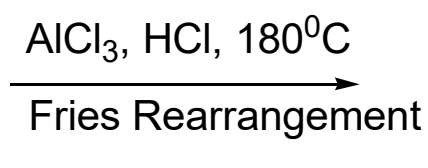<smiles>Cc1cc(O)c(C(=O)c2ccccc2)cc1Cl</smiles>

\section{Scheme III: Preparation of tetradentate Schiff base ligands}

The dibasic tetradentate chiral Schiff base ligands N,N'-bis(5-chloro-4-methyl-2-hydroxybenzophenone)ethylenediammine $\left(\mathrm{L}_{1}\right)$, N,N'-bis(5-chloro-4-methyl-2-hydroxybenzophenone)propylenediammine $\left(\mathrm{L}_{2}\right)$ and N,N'-bis(5-chloro-4-methyl-2-hydroxybenzophenone)o-phenylenediammine $\left(\mathrm{L}_{3}\right)$ were prepared by the following procedure:

5-chloro-4-methyl-2-hydroxybenzophenone $(49.52 \mathrm{mg})$ in methanol $(10 \mathrm{ml})$ was added to a solution of the ethylenediamine (1 mmole) under refluxtion for $1 \mathrm{hr}$ to obtain N,N'-bis(5-chloro-4-methyl-2-hydroxy benzophenone)ethylenediammine $\left(\mathrm{L}_{1}\right)$.

Similar procedure was followed for the preparation of Schiff base ligands such as N,N'-bis(5-chloro-4-methyl-2-hydroxy benzophenone)propylenediammine $\left(\mathrm{L}_{2}\right)$ and N,N'-bis(5-chloro-4-methyl-2-hydroxy benzophenone) $o$-phenylenediammine $\left(\mathrm{L}_{3}\right)$. 

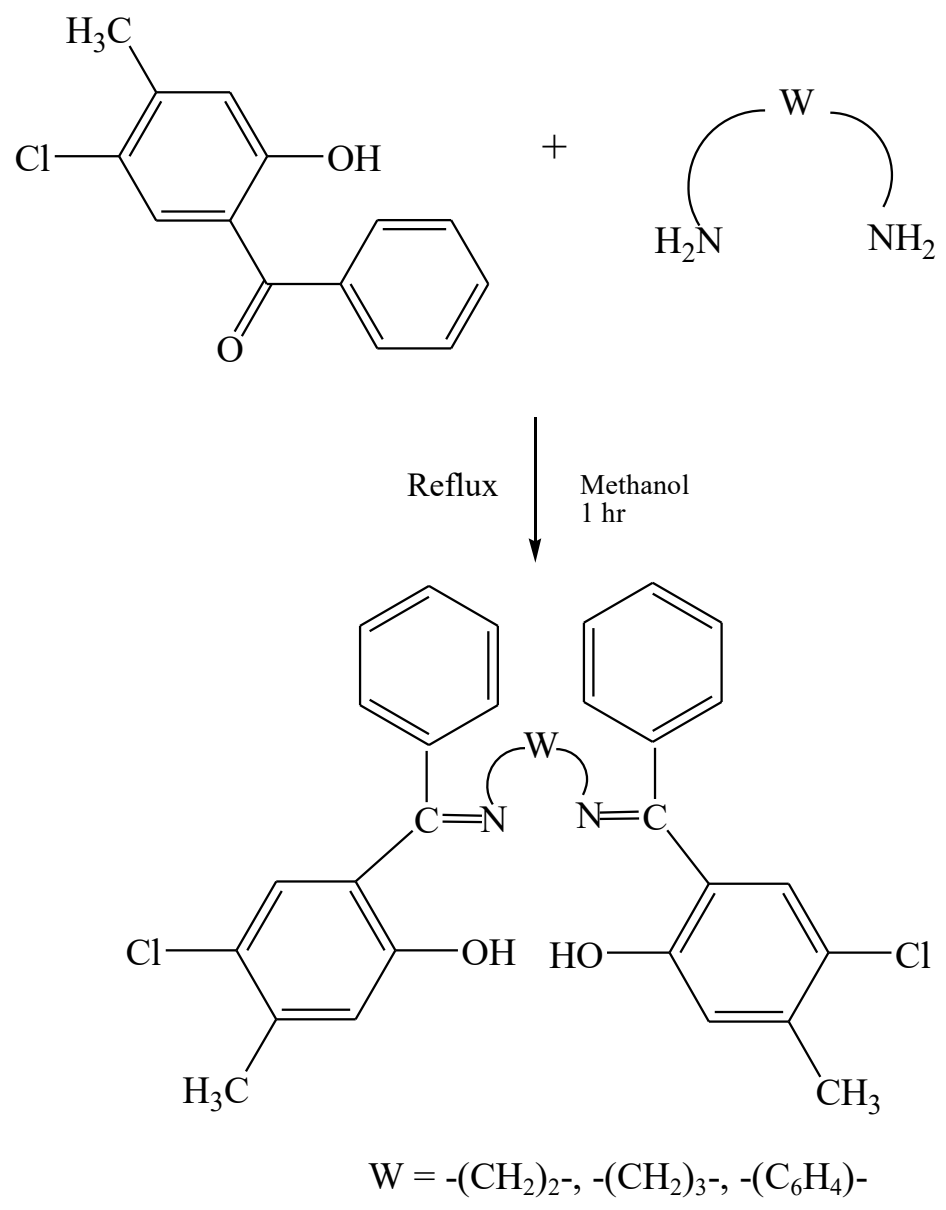

\section{3. Synthesis of new Ru(II) carbonyl Schiff base complexes}

To a benzene solution of $\left[\operatorname{RuHCl}(\mathrm{CO})(\mathrm{B})\left(\mathrm{EPh}_{3}\right)_{2}\right]$ (where $\mathrm{E}=\mathrm{P}$, $\mathrm{B}=\mathrm{PPh}_{3}$, py, pip; $\left.\mathrm{E}=\mathrm{As}, \mathrm{B}=\mathrm{AsPh}_{3}\right)(100 \mathrm{mg}, 0.09-0.12 \mathrm{mmol})$ was added to the appropriate ligand ethylenediamine $\left(\mathrm{L}_{1}\right)$ or propylenediamine $\left(\mathrm{L}_{2}\right)$ or $o$-phenylenediamine $\left(\mathrm{L}_{3}\right)$ (40-60 mg, 0.1-0.14 mmol) and the mixture was refluxed for $6 \mathrm{hr}$.

The reaction mixture colour changed gradually and the reactions were monitored by TLC. The solution was concentrated to about $3 \mathrm{ml}$ and pet. ether $\left(60-80{ }^{\circ} \mathrm{C}\right)$ was added to obtain solid which was separated by filtration. The crude product of the resulting complexes was purified by column chromatography using chloroform/acetone mixture as eluent. On evaporation of the resulting solution, pure compounds were obtained which was dried under vacuum. Using similar procedure the following complexes were prepared.

(1) $\left[\mathrm{Ru}(\mathrm{CO})\left(\mathrm{PPh}_{3}\right)\left(\mathrm{L}_{1}\right)\right]$

This is prepared from $\left[\mathrm{RuHCl}(\mathrm{CO})\left(\mathrm{PPh}_{3}\right)_{3}\right](100 \mathrm{mg})$ and $\mathrm{L}_{1}(54.45 \mathrm{mg})$ in benzene $(20 \mathrm{ml})$. Yield: $30 \mathrm{mg}$, Colour: Green, Melting point: $145^{\circ} \mathrm{C}$. 


\section{(2) $\left[\operatorname{Ru}(\mathrm{CO})(\mathrm{py})\left(\mathrm{L}_{1}\right)\right]$}

This is prepared from $\left[\mathrm{RuHCl}(\mathrm{CO})(\mathrm{py})\left(\mathrm{PPh}_{3}\right)_{2}\right](100 \mathrm{mg})$ and $\mathrm{L} 1(67.45 \mathrm{mg})$ in benzene $(20 \mathrm{ml})$. Yield: $33 \mathrm{mg}$, Colour: Green, Melting point: $143^{\circ} \mathrm{C}$.

\section{(3) $\left[\operatorname{Ru}(\mathrm{CO})(\mathrm{pip})\left(\mathrm{L}_{1}\right)\right]$}

This is prepared from $\left[\mathrm{RuHCl}(\mathrm{CO})(\right.$ pip $\left.)\left(\mathrm{PPh}_{3}\right)_{2}\right](100 \mathrm{mg})$ and $\mathrm{L} 1(66.97 \mathrm{mg})$ in benzene $(20 \mathrm{ml})$. Yield: $38 \mathrm{mg}$, Colour: Green, Melting point: $173^{\circ} \mathrm{C}$

(4) $\left[\mathrm{RuCO}\left(\mathrm{AsPh}_{3}\right)\left(\mathrm{L}_{1}\right)\right]$

This is prepared from $\left[\mathrm{RuHCl}(\mathrm{CO})\left(\mathrm{AsPh}_{3}\right)_{3}\right] \quad(100 \mathrm{mg})$ and L1 (47.89 mg) in benzene $(20 \mathrm{ml})$. Yield: $35 \mathrm{mg}$, Colour: Yellow, Melting point: $146^{\circ} \mathrm{C}$

\section{(5) $\left[\mathrm{Ru}(\mathrm{CO})\left(\mathrm{PPh}_{3}\right)\left(\mathrm{L}_{2}\right)\right]$}

This is prepared from $\left[\mathrm{RuHCl}(\mathrm{CO})\left(\mathrm{PPh}_{3}\right)_{3}\right] \quad(100 \mathrm{mg})$ and L2 $(55.98 \mathrm{mg})$ in benzene $(20 \mathrm{ml})$. Yield: $33 \mathrm{mg}$, Colour: Green, Melting point: $153{ }^{\circ} \mathrm{C}$

(6) $\left[\operatorname{Ru}(\mathrm{CO})(\mathrm{py})\left(\mathrm{L}_{2}\right)\right]$

This is prepared from $\left[\mathrm{RuHCl}(\mathrm{CO})(\mathrm{py})\left(\mathrm{PPh}_{3}\right)_{2}\right] \quad(100 \quad \mathrm{mg})$ and L2 $(69.3 \mathrm{mg})$ in benzene $(20 \mathrm{ml})$. Yield: $25 \mathrm{mg}$, Colour: Green, Melting point: $148^{\circ} \mathrm{C}$

(7) $\left[\operatorname{Ru}(\mathbf{C O})(\operatorname{pip})\left(\mathbf{L}_{2}\right)\right]$

This is prepared from $\left[\mathrm{RuHCl}(\mathrm{CO})(\right.$ pip $\left.)\left(\mathrm{PPh}_{3}\right)_{2}\right](100 \mathrm{mg})$ and $\mathrm{L} 2(52.13 \mathrm{mg})$ in benzene $(20 \mathrm{ml})$. Yield: $30 \mathrm{mg}$, Colour: Green, Melting point: $172{ }^{\circ} \mathrm{C}$

(8) $\left[\mathrm{RuCO}\left(\mathrm{AsPh}_{3}\right)\left(\mathrm{L}_{2}\right)\right]$

This is prepared from $\left[\mathrm{RuHCl}(\mathrm{CO})\left(\mathrm{AsPh}_{3}\right)_{3}\right](100 \mathrm{mg})$ and $\mathrm{L} 2(49.19 \mathrm{mg})$ in benzene $(20 \mathrm{ml})$. Yield: $30 \mathrm{mg}$, Colour: yellow, Melting point: $167^{\circ} \mathrm{C}$

\section{(9) $\left[\mathrm{Ru}(\mathrm{CO})\left(\mathrm{PPh}_{3}\right)\left(\mathrm{L}_{3}\right)\right]$}

This is prepared from $\left[\mathrm{RuHCl}(\mathrm{CO})\left(\mathrm{PPh}_{3}\right)_{3}\right](100 \mathrm{mg})$ and $\mathrm{L} 3(5.96 \mathrm{mg})$ in benzene $(20$ $\mathrm{ml})$. Yield: $35 \mathrm{mg}$, Colour: Green, Melting point: $174{ }^{\circ} \mathrm{C}$

\section{(10) $\left[\operatorname{Ru}(\mathrm{CO})(\mathrm{py})\left(\mathrm{L}_{3}\right)\right]$}

This is prepared from $\left[\mathrm{RuHCl}(\mathrm{CO})(\mathrm{py})\left(\mathrm{PPh}_{3}\right)_{2}\right](100 \mathrm{mg})$ and $\mathrm{L} 3(73.75 \mathrm{mg})$ in benzene $(20 \mathrm{ml})$. Yield: $38 \mathrm{mg}$, Colour: Brown, Melting point: $148^{\circ} \mathrm{C}$

\section{(11) $\left[\operatorname{Ru}(\mathbf{C O})(\mathrm{pip})\left(\mathrm{L}_{3}\right)\right]$}

This is prepared from $\left[\mathrm{RuHCl}(\mathrm{CO})(\mathrm{pip})\left(\mathrm{PPh}_{3}\right)_{2}\right](100 \mathrm{mg})$ and $\mathrm{L} 3(73.17 \mathrm{mg})$ in benzene $(20 \mathrm{ml})$. Yield: $34 \mathrm{mg}$, Colour: Brown, Melting point: $178^{\circ} \mathrm{C}$

(12) $\left[\mathrm{RuCO}\left(\mathrm{AsPh}_{3}\right)\left(\mathrm{L}_{3}\right)\right]$

This is prepared from $\left[\mathrm{RuHCl}(\mathrm{CO})\left(\mathrm{AsPh}_{3}\right)_{3}\right](100 \mathrm{mg})$ and $\mathrm{L} 3(5.23 \mathrm{mg})$ in benzene $(20 \mathrm{ml})$. Yield: $40 \mathrm{mg}$, Colour: Brown, Melting point: $170^{\circ} \mathrm{C}$. 


\section{RESULTS AND DISCUSSION}

The new tetradentate Schiff base complexes of the type $[\mathrm{Ru}(\mathrm{CO})(\mathrm{B})(\mathrm{L})]$ (where $\mathrm{B}=$ $\mathrm{PPh}_{3}, \mathrm{AsPh}_{3}$, py or pip) have been obtained from the reaction of $\left[\mathrm{RuHCl}(\mathrm{CO})(\mathrm{B})\left(\mathrm{EPh}_{3}\right)\right]$ (where $\mathrm{E}=\mathrm{P}, \mathrm{B}=\mathrm{PPh}_{3}$ and py; $\mathrm{E}=\mathrm{As}, \mathrm{B}=\mathrm{AsPh}_{3}$,) with various tetradentate Schiff bases viz., $\mathrm{L}_{1}, \mathrm{~L}_{2}$ and $\mathrm{L}_{3}$ in dry benzene in 1:1 molar ratio as shown in the general equation given below:

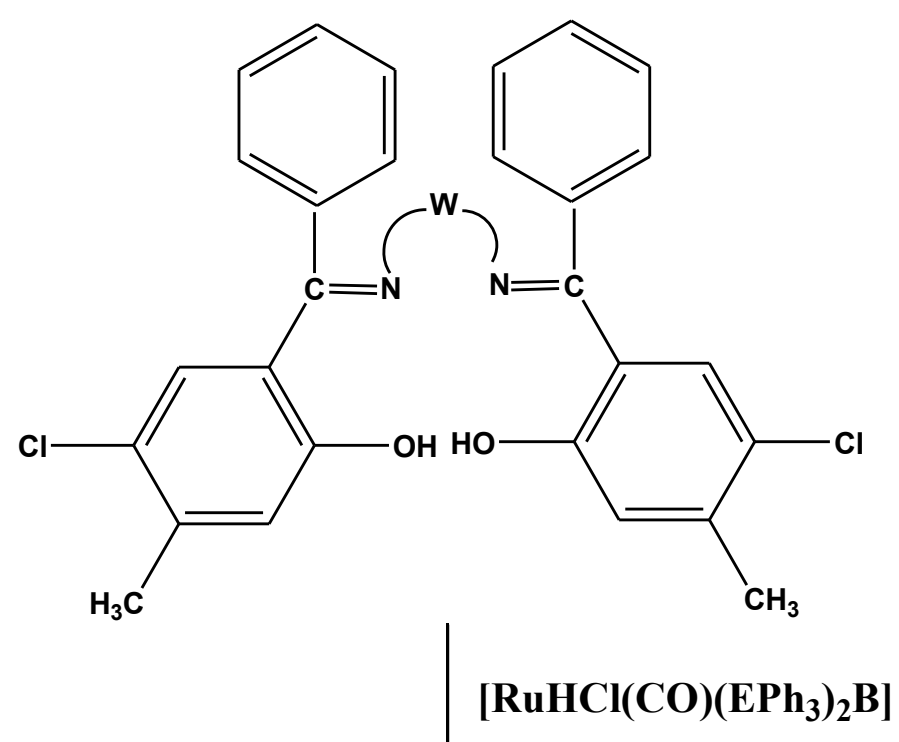

\section{Reflux / 6 hr Benzene}

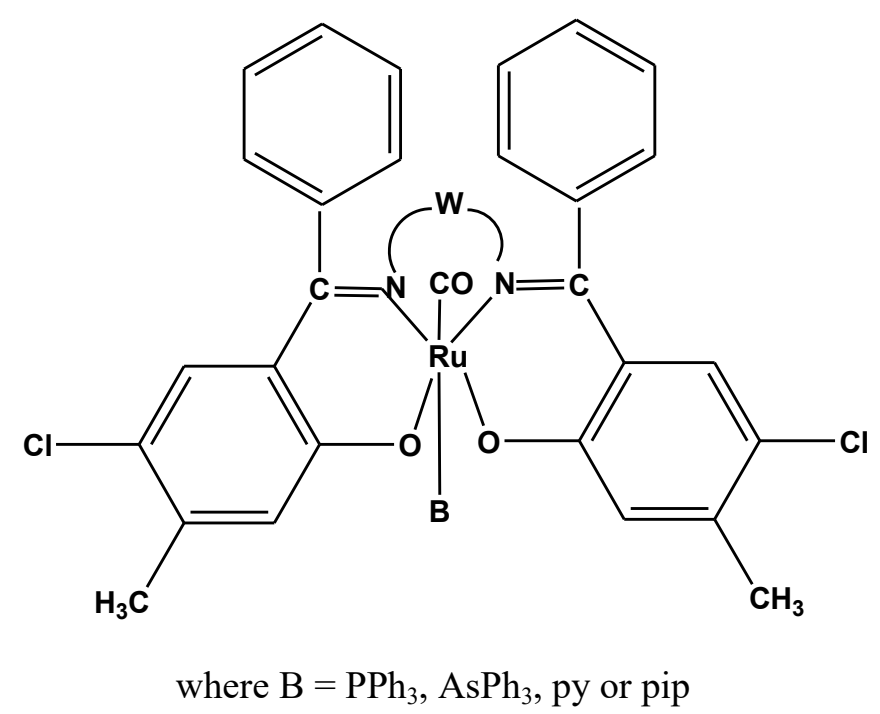

Fig. 1. Formation of Ru(II) carbonyl Schiff base complexes 
Table 1. Analytical data for Ru(II) Schiff base complexes.

\begin{tabular}{|c|c|c|c|c|c|c|}
\hline \multirow{2}{*}{ S. No } & \multirow{2}{*}{ Complexes } & \multirow{2}{*}{ Color } & \multirow{2}{*}{$\begin{array}{l}\text { m. } \mathbf{p} \\
\left({ }^{\circ} \mathbf{C}\right)\end{array}$} & \multicolumn{3}{|c|}{ Calculated (Found \%) } \\
\hline & & & & $\mathbf{C}$ & $\mathbf{H}$ & $\mathbf{N}$ \\
\hline 1 & {$\left[\mathrm{Ru}(\mathrm{CO})\left(\mathrm{PPh}_{3}\right)\left(\mathrm{L}_{1}\right)\right]$} & Green & 145 & $64.79(64.30)$ & $4.3(4.21)$ & $3.08(2.94)$ \\
\hline 2 & {$\left[\mathrm{Ru}(\mathrm{CO})(\mathrm{py})\left(\mathrm{L}_{1}\right)\right]$} & Green & 143 & - & - & - \\
\hline 3 & {$\left[\mathrm{Ru}(\mathrm{CO})(\mathrm{py})\left(\mathrm{L}_{1}\right)\right]$} & Green & 173 & - & - & - \\
\hline 4 & {$\left[\mathrm{Ru}(\mathrm{CO})\left(\mathrm{AsPh}_{3}\right)\left(\mathrm{L}_{1}\right)\right]$} & Yellow & 146 & $64.79(63.93)$ & $4.1(3.98)$ & $2.9(2.83)$ \\
\hline 5 & {$\left[\mathrm{Ru}(\mathrm{CO})\left(\mathrm{PPh}_{3}\right)\left(\mathrm{L}_{2}\right)\right]$} & Green & 145 & - & - & - \\
\hline 6 & {$\left[\mathrm{Ru}(\mathrm{CO})(\mathrm{py})\left(\mathrm{L}_{2}\right)\right]$} & Green & 144 & - & - & - \\
\hline 7 & {$\left[\mathrm{Ru}(\mathrm{CO})(\mathrm{pip})\left(\mathrm{L}_{2}\right)\right]$} & Green & 172 & - & - & - \\
\hline 8 & {$\left[\mathrm{Ru}(\mathrm{CO})\left(\mathrm{AsPh}_{3}\right)\left(\mathrm{L}_{2}\right)\right]$} & Yellow & 167 & $61.9(61.10)$ & $4.28(4.23)$ & $2.89(2.73)$ \\
\hline 9 & {$\left[\mathrm{Ru}(\mathrm{CO})\left(\mathrm{PPh}_{3}\right)\left(\mathrm{L}_{3}\right)\right]$} & Brown & 174 & $66.53(66.09)$ & 4.1(3.92) & $2.9(2.88)$ \\
\hline 10 & {$\left[\mathrm{Ru}(\mathrm{CO})(\mathrm{py})\left(\mathrm{L}_{3}\right)\right]$} & Brown & 148 & - & - & - \\
\hline 11 & {$\left[\mathrm{Ru}(\mathrm{CO})(\mathrm{pip})\left(\mathrm{L}_{3}\right)\right]$} & Brown & 176 & - & - & - \\
\hline 12 & {$\left[\mathrm{Ru}(\mathrm{CO})\left(\mathrm{AsPh}_{3}\right)\left(\mathrm{L}_{3}\right)\right]$} & Brown & 170 & $63.61(63.25)$ & $3.93(2.39)$ & $2.79(2.43)$ \\
\hline
\end{tabular}


All the new tetradentate Schiff base ruthenium(II) carbonyl complexes are green and brown in colour, stable in air, non-hygroscopic in nature and highly soluble in common solvents such as dichloromethane, acetonitrile and chloroform producing intense green and brown solutions. The analytical data are given in Table 1 and are good agreement with general molecular formula proposed.

\section{FT-IR SPECTRA}

In order to study the binding mode of the Schiff bases to ruthenium in the new complexes, the IR spectra of the Schiff bases were compared to the spectra of the ruthenium(II) complexes.

The free Schiff bases show a very strong absorption around $1615-1600 \mathrm{~cm}^{-1}$ which is characteristic of the azomethine $(>\mathrm{C}=\mathrm{N})$ group ${ }^{1}$. If the Schiff bases coordinate through the nitrogen atom, it is expected that there must be a reduction in the azomethine $(>\mathrm{C}=\mathrm{N})$ frequency due to the lowering of electron density upon coordination.

Table 2. IR spectral data for Ru(II) Schiff base ligands.

\begin{tabular}{|c|c|c|c|}
\hline Ligands & $\begin{array}{c}\mathbf{v}_{\mathbf{C}=\mathbf{N}} \\
\left(\mathbf{c m}^{-1}\right)\end{array}$ & $\begin{array}{c}\mathbf{v}_{\mathbf{C}-\mathbf{O}} \\
\left(\mathbf{c m}^{-1}\right)\end{array}$ & $\begin{array}{c}\mathbf{v}_{\mathbf{O H}} \\
\left(\mathbf{c m}^{-1}\right)\end{array}$ \\
\hline $\mathrm{L}_{1}$ & 1610 & 1386 & 3440 \\
\hline $\mathrm{L}_{2}$ & 1608 & 1377 & 3417 \\
\hline $\mathrm{L}_{3}$ & 1604 & 1338 & 3379 \\
\hline
\end{tabular}

In the IR spectra of all the complexes azomethine group $(>\mathrm{C}=\mathrm{N})$ is observed at a lower region around (1625-1580 $\left.\mathrm{cm}^{-1}\right)$, indicating the coordination of nitrogen atom of the Schiff base to the ruthenium ${ }^{2}$ and also this coordination is further supported when the energies of the azomethine $(>\mathrm{C}=\mathrm{N})$ stretching vibration of the ligands are compared with those of their respective ruthenium(II) complexes, a shift of $4-28 \mathrm{~cm}^{-1}$ to lower energies is observed in all complexes, a consequence of metal binding to the imine nitrogen atoms, sustaining the coordination of the metal to the Schiff base ligands ${ }^{3,4}$.

A strong band observed around 1340-1386 $\mathrm{cm}^{-1}$ in the free Schiff bases has been assigned to phenolic $\mathrm{C}-\mathrm{O}$ stretching. On complexation, this band has been shifted to higher frequency 1412-1440 $\mathrm{cm}^{-1}$ showing the other coordination site is the phenolic oxygen.This was further supported by disappearance of band around $3379-3438 \mathrm{~cm}^{-1}$ due to $v(\mathrm{OH})$ of free ligands in the spectra of all the complexes, indicating the deprotonation of Schiff bases prior to coordination through its oxygen atom.

For all the complexes, the IR spectra showed a strong band in the region $1937-1959 \mathrm{~cm}^{-}$ ${ }^{1}$ due to terminally coordinated carbonyl group which occurs at higher frequency than the starting precursors. 
Table 3. IR spectral data for Ru(II) Schiff base complexes.

\begin{tabular}{|c|c|c|c|}
\hline Complexes & $\begin{array}{c}V_{C=N} \\
\left(\mathrm{~cm}^{-1}\right)\end{array}$ & $\begin{array}{c}V_{\mathrm{C}-\mathrm{O}} \\
\left(\mathrm{cm}^{-1}\right)\end{array}$ & $\begin{array}{l}V_{\mathrm{C} \equiv \mathrm{O}} \\
\left(\mathrm{cm}^{-1}\right)\end{array}$ \\
\hline 1 & 1598 & 1434 & 1957 \\
\hline 2 & 1580 & 1435 & 1958 \\
\hline 5 & 1638 & 1432 & 1951 \\
\hline 6 & 1601 & 1412 & 1937 \\
\hline 7 & 1599 & 1434 & 1943 \\
\hline 9 & 1612 & 1424 & 1950 \\
\hline 10 & 1620 & 1434 & 1952 \\
\hline 11 & 1612 & 1438 & 1956 \\
\hline 12 & 1623 & 1435 & 1954 \\
\hline
\end{tabular}

For all the complexes, the IR spectra showed a medium intensity band in the region around $1090 \mathrm{~cm}^{-1}$ which is characteristic of coordinated nitrogen bases. Characteristic bands for the coordination of triphenylphosphine were also present around $1432-1436 \mathrm{~cm}^{-1}$ in the spectra of all the complexes.

\section{ELECTRONIC SPECTRA}

The electronic spectra of all the complexes were recorded in dichloromethane and spectral data are presented in Table 2. All the new Schiff base ruthenium(II) complexes are 
diamagnetic, indicating the presence of ruthenium in the +2 oxidation state. The ground state of ruthenium(II) in an octahedral environment is ${ }^{1} \mathrm{~A}_{1 \mathrm{~g}}$ arising from the $\mathrm{t}^{6}{ }_{2 \mathrm{~g}}$ configuration.

Table 4. Electronic spectral data of Ru(II) Schiff base complexes.

\begin{tabular}{|c|c|}
\hline Complexes & $\lambda_{\max }(\mathrm{nm})(\varepsilon)\left(\mathrm{dm}^{3} \mathrm{~mol}^{-1} \mathrm{~cm}^{-1}\right)$ \\
\hline 1 & $678^{\mathrm{a}}(968), 341^{\mathrm{c}}(9363), 280^{\mathrm{c}}(16,337)$ \\
\hline 2 & $426^{\mathrm{b}}(6589), 324^{\mathrm{c}}(16,333), 268^{\mathrm{c}}(36,761)$ \\
\hline 3 & $646^{\mathrm{a}}(792), 460^{\mathrm{b}}(2720), 324^{\mathrm{c}}(9238), 270^{\mathrm{c}}(28,438)$ \\
\hline 4 & $423^{\mathrm{b}}(3076), 320^{\mathrm{c}}(8813), 272^{\mathrm{c}}(24,428)$ \\
\hline 5 & $688^{\mathrm{a}}(1274), 450^{\mathrm{b}}(3746), 330^{\mathrm{c}}(21,254), 270^{\mathrm{c}}(25,456)$ \\
\hline 6 & $430^{\mathrm{b}}(4768), 340^{\mathrm{c}}(20,143), 265^{\mathrm{c}}(20,142)$ \\
\hline 7 & $667^{\mathrm{a}}(953), 442^{\mathrm{b}}(4902), 318^{\mathrm{c}}(14,382), 265^{\mathrm{c}}(30,656)$ \\
\hline 8 & $670^{\mathrm{a}}(1569), 441^{\mathrm{b}}(5998), 321^{\mathrm{c}}(15,078), 311^{\mathrm{c}}(16,061)$ \\
\hline 9 & $441^{\mathrm{b}}(1977), 313^{\mathrm{c}}(8856), 274^{\mathrm{c}}(23,969), 262^{\mathrm{c}}(39,876)$ \\
\hline 10 & $433^{\mathrm{b}}(8062), 326^{\mathrm{c}}(22,286), 267^{\mathrm{c}}(29,558)$ \\
\hline 11 & $448^{\mathrm{b}}(1666), 311^{\mathrm{c}}(6759), 271^{\mathrm{c}}(18,333)$ \\
\hline 12 & $658^{\mathrm{a}}(724), 447^{\mathrm{b}}(1576), 265^{\mathrm{c}}(18,682), 249^{\mathrm{c}}(22,255)$ \\
\hline
\end{tabular}

The excited states corresponding to the $\mathrm{t}^{5}{ }_{2 \mathrm{~g}}$ eg ${ }^{1}$ configuration are ${ }^{3} \mathrm{~T}_{1 \mathrm{~g}},{ }^{3} \mathrm{~T}_{2 \mathrm{~g}},{ }^{1} \mathrm{~T}_{1 \mathrm{~g}}$ and ${ }^{1} \mathrm{~T}_{2 \mathrm{~g}}$. Hence, four bands corresponding ${ }^{1} \mathrm{~A}_{1} \mathrm{~g} \rightarrow{ }^{3} \mathrm{~T}_{1} \mathrm{~g},{ }^{1} \mathrm{~A}_{1} \mathrm{~g} \rightarrow{ }^{3} \mathrm{~T}_{2} \mathrm{~g},{ }^{1} \mathrm{~A}_{1} \mathrm{~g} \rightarrow{ }^{1} \mathrm{~T}_{1} \mathrm{~g},{ }^{1} \mathrm{~A}_{1} \mathrm{~g} \rightarrow{ }^{1} \mathrm{~T}_{2} \mathrm{~g}$ are possible in the order of increasing energy. The electronic spectra showed bands in the region around $680-658 \mathrm{~nm}$ which are assigned to ${ }^{1} \mathrm{~A}_{1} \mathrm{~g} \rightarrow{ }^{1} \mathrm{~T}_{1} \mathrm{~g}$.

The other high intensity bands observed around $456-423 \mathrm{~nm}$ region has been assigned to metal to ligand charge transfer transition (MLCT) arising from the excitation of electrons from the metal $t_{2 g}$ level to the unfilled molecular orbitals derived from the $\pi$ level of the ligands. The absorption spectra of dichloromethane solutions of the complexes are also characterized by intense ligand-centered (LC) bands with maxima in the 346-236 nm region.

These bands have been designated as $\pi-\pi^{*}$ and $n-\pi^{*}$ transitions for the electrons localized on the azomethine group of the Schiff base ligand. 
These assignments are in accordance with the assignment for similar ruthenium(II) octahedral complexes based on molar extinction coefficients.

\section{${ }^{1}$ H-NMR SPECTRA}

The ligand to metal binding in the new ruthenium(II) complexes is further supported by the ${ }^{1} \mathrm{H}-\mathrm{NMR}$ spectra.

Table 5. ${ }^{1} \mathrm{H}-\mathrm{NMR}$ spectral data of Schiff base ligands.

\begin{tabular}{|c|c|c|c|c|}
\hline Ligand & $\begin{array}{c}\mathbf{A r}-\mathbf{H} \\
\mathbf{( p p m )}\end{array}$ & $\begin{array}{c}\mathbf{C H}_{\mathbf{3}} \\
\mathbf{( p p m )}\end{array}$ & $\begin{array}{c}\mathbf{C H} \\
\mathbf{( \mathbf { p p m } )}\end{array}$ & $\begin{array}{c}\mathbf{O H} \\
\mathbf{( p p m )}\end{array}$ \\
\hline $\mathrm{L}_{1}$ & $6.8-7.2$ & 2.4 & 3.6 & 14 \\
\hline $\mathrm{L}_{2}$ & $6.9-7.2$ & 2.6 & 3.8 & 14 \\
\hline $\mathrm{L}_{3}$ & $6.8-7.4$ & 2.6 & --- & 12 \\
\hline
\end{tabular}

Table 6. ${ }^{1} \mathrm{H}-\mathrm{NMR}$ spectral data of Ru(II) carbonyl Schiff base complexes.

\begin{tabular}{|c|c|c|c|}
\hline Complexes & $\begin{array}{c}\mathbf{A r}-\mathbf{H} \\
\mathbf{( p p m )}\end{array}$ & $\begin{array}{c}\mathbf{C H}_{\mathbf{3}} \\
\mathbf{( p p m )}\end{array}$ & $\begin{array}{c}\mathbf{C H}_{\mathbf{2}} \\
\mathbf{( p p m )}\end{array}$ \\
\hline 1 & $7-7.4$ & 1.6 & 2.8 \\
\hline 2 & $6.8-7.8$ & 1.6 & 2.8 \\
\hline 5 & $7.2-7.6$ & 1.6 & - \\
\hline 9 & $7.2-7.8$ & 1.8 & - \\
\hline 10 & $7.2-7.8$ & 1.8 & - \\
\hline 12 & $7.2-7.8$ & 1.8 & \\
\hline
\end{tabular}


The multiplet observed in the region around $\delta 6.8-7.8 \mathrm{ppm}$ in all the listed complexes have been assigned to the aromatic protons of the phenyl group of the triphenylphosphine or Arsine, the Schiff base ligands and the heterocyclic nitrogen bases. The signal in the region 2.6-3.3 ppm is due to methylene protons nearer to nitrogen. As the methyl protons are attached to the phenyl ring the signal for these protons in the complexes appear in the upfield region $\delta 1.6-1.8 \mathrm{ppm}$ and the selected spectra are shown. The absence of a resonance in the region $\delta 12-14.0 \mathrm{ppm}$ in the complexes indicate deprotonation of the phenolic $(-\mathrm{OH})$ group of the Schiff bases on complexation and coordination to ruthenium through the phenolic oxygen.

\section{CONCLUSION}

The synthesis and characterization of hexa co-ordinated ruthenium(II) complexes of the type $[\mathrm{Ru}(\mathrm{CO})(\mathrm{B})(\mathrm{L})]$ (where $\mathrm{B}=\mathrm{PPh}_{3}, \mathrm{AsPh}_{3}$, py or pip and $\mathrm{L}=$ dibasic tetradentate Schiff base ligand) were synthesized from the reaction of $\left[\mathrm{RuHCl}(\mathrm{CO})(\mathrm{B})\left(\mathrm{EPh}_{3}\right)_{2}\right]($ where $\mathrm{E}=$ $\mathrm{P}, \mathrm{B}=\mathrm{PPh}_{3}$, py or pip, $\mathrm{E}=\mathrm{As}, \mathrm{B}=\mathrm{AsPh}_{3}$ ) with different tetradentate ligands. The ligands were derived by the condensation of 5-chloro-4-methyl-2-hydroxy benzophenone with ethylenediamine, propylenediamine and $o$-phenylene-diamine in 1:1 molar ratio. All the compounds have been characterized by elemental analysis and spectral (FT-IR, UV-VIS and ${ }^{1} \mathrm{H}-\mathrm{NMR}$ ) methods. An octahedral environment around $\mathrm{Ru}(\mathrm{II})$ ion has been tentatively proposed for all the complexes.

\section{References}

[1]. A. M. El-Hendawy, A. H. Alkubasi, A. El-Ghany, K. El-Kourashym, M. N. Sharab, Polyhedron 20 (2001) 975.

[2]. P. K. Bhattacharya, Proc. Ind. Acad. Sci. (Chem. Sci.) 102 (1990) 247.

[3]. A. Bader, E. Linder, Coord. Chem. Rev. 27 (1991) 108.

[4]. C. Slugove, P. Wiede, K. Mereiter, R. Schmid, K. Kirchner, Organometallics 16 (1997) 2768.

[5]. F. Mevellec, S. Collet, D. Deniaud, A. Reliquet, J. Meslin, J. Chem. Soc. (2001) 3128.

[6]. V. R. de Souza, G. S. Nunes, R. C. Rocha, H. E. Toma, Inorg. Chim. Acta. 348 (2003) 50 .

[7]. A. D. Garnovskii, A. L. Nivorozhkin, V. I. Minkin, Coord. Chem. Rev. 126 (1993).

[8]. R. Ziessel, Coord. Chem. Rev. 195 (2001) 216.

[9]. C. A. McAuliffe, W. Leavason, Phosphine, Arsine and Stilbine Complexes of the Transition Elements, Elseiver, Amsterdam, 1979.

[10]. K.-I. Na, S. Huh, K. M. Sung, M. -Jun, Polyhedron 15 (1996) 1841.

[11]. M. Ito, M. Hirakawa, K. Murata, T. Ikariya, Organometallics 20 (2001) 379. 
[12]. G. P. C. M. Dekker, A. Bujis, C. J. Elsevier, K. Vrieze, P. W. N. M. Van Leeuwen, W.

J. J. Smeets, A. L. Spek, Y. F. Wang, C. H. Stam, Organometallics 11 (1992) 1937.

[13]. A. Habtemariam, B. Watchman, B. S. Potter, R. Palmer, S. Parsons, A. Parkin, P. J. Sadler, J. Chem. Soc. Dalton Trans. (2001) 1306.

[14]. A. Mansour, M. Portnoy, J. Chem. Soc. Perkin Trans. 1 (2001) 952.

[15]. A. Das, S.-M. Peng, G.-H. Lee, S. Bhattacharya, New. J. Chem. 28 (2004) 712.

[16]. L. N. Ji, X. -H. Zou, J. -G. Liu, Coord. Chem. Rev. 513 (2001) 216.

[17]. S. I. Gorelsky, A. B. P. Lever, M. Ebadi, Coord. Chem. Rev. 97 (2002) 230.

[18]. M. J. Clarke, Coord. Chem. Rev. 209 (2003) 236.

[19]. B. Serli, E. Zangrrando, T. Gianferrara, L. Yellowless, E. Alessio, Coord. Chem. Rev. 73 (2003) 245.

[20]. X. -G. Zhou, J. -S. Huang, P. -H. Ko, K. -K. Cheung, C. -M. Che, J. Chem. Soc. Dalton Trans. (1999) 3303.

[21]. W. Ruttinger, G. C. Dismukes, Chem. Rev. 1 (1997) 97.

[22]. W. Odenkirk, A. L. Rheingold, B. Bosnich, J. Am. Chem. Soc. 114 (1992) 6392.

[23]. M. L. P. Santos, I. A. Bagatin, E. M. Pereira, A. M. C.Ferreira, J. Chem. Soc., Dalton Trans. (2001) 838.

[24]. S. Menage, J. -B. Galey, J. Dumats, G. Hussler, M. Seite, J. Am. Chem. Soc. 120 (1998) 13370.

[25]. J. -P. Costes, F. Dahan, A. Dupuis, J. -P. Laurent, J. Chem. Soc. Dalton Trans. (1998) 1307.

[26]. E. -G. Jager, J. Knaudt, M. Rudolph, M. Rost, Chem. Ber. 129 (1996) 1041.

[27]. S. R. Collinson, D. E. Fenton, Coord. Chem. Rev. 19 (1996) 148. 